\title{
ФУНКЦІОНАЛЬНО-СТИЛІСТИЧНІ ВИЯВИ ІНШОМОВНИХ ЛЕКСЕМ У РОЗВАЖАЛЬНИХ ЖАНРАХ
}

\author{
ЮЛІЯ МОЛОТКІНА \\ ДВНЗ „Переяслав-Хмельницький державний педагогічний \\ університет імені Григорія Сковороди", Переяслав-Хмельницький - Україна \\ molotkina_92@meta.ua; ORCID:0000-0002-5245-726X

\section{FUNKCJONALNO-STYLISTYCZNE CECHY LEKSEMÓW ZAPOŻYCZONYCH W ROZRYWKOWYCH GATUNKACH TELEWIZYJNYCH}

JULIIA MOŁOTKINA

Państwowa Szkoła Wyższa „Perejasław-Chmielnicki Państwowy Uniwersytet Pedagogiczny imienia Hryhorija Skoworody", Perejasław-Chmielnicki — Ukraina

STRESZCZENIE. Artykuł analizuje najnowsze zapożyczenia językowe pojawiające się w trakcie emisji współczesnych ukraińskich programów humorystycznych i rozrywkowych oraz popularnego serialu młodzieżowego. Dowiedziono, iż zapożyczenia językowe wykorzystywane są nie tylko w postaci wtrąceń obcojęzycznych, ale również ulegają zmianom w zakresie obszaru semantycznego, zyskując nowe zabarwienie stylistyczne.

Słowa kluczowe: współczesny język ukraiński, styl dziennikarski, gatunki rozrywkowe, zapożyczenia, struktura semantyczna, anglicyzm.

\section{FUNCTIONAL AND STYLISTIC LOANWORDS EXPRESSIONS IN THE ENTERTAINMENT GENRES}

\author{
YULIIA MOLOTKINA \\ Pereiaslav-Khmelnytskyi Hryhorii Skovoroda State Pedagogical University, \\ Pereiaslav-Khmelnytskyi — Ukraine
}

ABSTRACT. The article deals with the new lexical borrowings analysis in the discourse of the modern Ukrainian comedy shows, entertainment programs and popular youth series. It has been proved that foreign borrowed lexemes are used not just in terms of foreign language lexical units; they experience the semantic structure changes and obtain the new stylistic expressions.

Key words: modern Ukrainian language, journalistic style, entertainment genres, lexical borrowing, semantic structure, anglicisms.

\footnotetext{
$\mathrm{C}$

учасні 3МІ послідовно відображають суспільні та мовні зміни, спостерігаємо певні трансформації, що відбуваються передусім на лексико-семантичному й словотвірному рівнях. Під впливом різноманітних мовних та позамовних чинників сучасний лексикон українських мас-медіа активно поповнюється словами іншомовного походження. Процеси запозичення суттєво впливають не лише на збагачення словникового складу сучасних українських 3MI, а й на комунікативну ефективність медійних жанрів.

Мовлення сучасного українського телебачення насичене різноманітними іншомовними лексемами (найчастіше англомовного походження). У кінці
} 
XX - на поч. XXI ст. запозичення здебільшого вживалися в дискурсі телевізійних служб новин та інформаційних передач, але протягом останнього десятиріччя вони все частіше трапляються в різних розважальних телепрограмах. Чужомовні слова вживаються не лише як іншомовні вкраплення, вони творчо обробляються, пристосовуючись до норм української мови, змінюють семантичну структуру та набувають різноманітних стилістичних виявів, що свідчить про їхню високу функціонально-стильову дифузність та глибокий ступінь освоєння на грунті сучасної української мови ${ }^{1}$.

Метою цієї розвідки є аналіз змін семантичної структури та функціонально-стилістичного забарвлення новітніх запозичень у мові сучасних українських розважальних телевізійних програм.

Одним із критеріїв освоєння іншомовної лексики мовою-рецептором $\epsilon$ іiі семантична адаптація. Існують такі основні типи семантичних процесів, що зазвичай відбуваються в системі запозичених лексем:

а) зміна семантичної структури іншомовного слова внаслідок збільшення чи зменшення семантичного обсягу;

б) утрата старого й розвиток нового значення запозиченого слова;

в) пристосування семантики нового запозичення до лексико-семантичної системи української мови ${ }^{2}$.

За цією класифікацією в ході дослідження виокремлено чотири групи новітніх запозичень у дискурсі розважальних телепрограм:

1) запозичення, що не зазнали змін семантичної структури й уживаються в розважальних програмах із тим самим значенням, що й у мові-джерелі;

2) іншомовні лексеми, що звузили своє значення;

3 ) слова чужомовного походження, що розширили свій семантичний обсяг;

4) запозичені слова, що набули іншої семантики порівняно з його значенням у мові-джерелі.

Отже, першу групу запозичень у розважальних жанрах становлять іншомовні слова, що не змінили своєї семантичної структури. Ця група включає такі лексико-семантичні підгрупи (далі ЛСП):

1.1. Власні назви фірм, корпорацій, сайтів, навчальних закладів та мобільних додатків, зокрема таких, як Джек Деніалс (англ. Jack Denials - марка віскі), Mepi Кей (англ. Mary Key - косметична фірма), Рендж Ровер (англ. Range Rover - марка машини), Фейсбук (англ. Facebook - назва соціальної Інтернет-мережі), Кембрідж (англ. Cambridge - англійське університетське місто), Бла-бла кар (англ. Blablacar - мобільний додаток) та ін., напр.: Ви щонебудь пили? - Ми що-небудь не п'єм... Джек Деніалс (“Вар'яти”, Сезон 2, вип. 4, 22.11.17); Ти теж консультант в банку? - В Мері Кей (“Вар'яти”, Сезон 2, вип. 3, 15.11.17); Я на новий Рендж Ровер як не мав, так $і$ не маю (“Вар'яти”, Сезон 2, вип. 5, 29.11.17); Ми недавно там на гастролях були, в Фейсбуці щось гортали і знайшли статтю (“Вар'яти”, Сезон 2, вип. 4, 22.11.17); Як я то можу поняти, що котлети в холодильнику, то треба Кембрідж закінчити, щоб поняти, що котлети в холодильнику (“Вар'яти”, Сезон 2, вип. 3, 15.11.17); Я сюда приїхав на Бла-бла карі з старою бабою, а знаєш як я розрахувався? ("Вар'яти”, Сезон 2, вип. 3, 15.11.17).

1 М. I. Навальна, Динаміка лексикону украӥнської періодики початку XXI cm., Київ 2011, c. 55.

${ }^{2}$ I. О. Коробова, Семантичне та словотвірне освосння новітніх запозичень в українській мові, Запоріжжя 2018, с. 9. 
1.2. До цієї ЛСП увійшли назви ввічливих іншомовних етикетних форм, що використовуються для окреслення особи, як-от: мicic (англ. Mrs), ледi (англ. lady), джентльмен (англ. gentlemen) та ін. Напр.: От бачили, леді в будьякій ситуації мусить залишатися леді (“Київ вдень та вночі", Сезон 4, сер. 46, 07.12.17); A місіс Лопес все ніяк свою фантазію не вгамує ("Київ вдень та вночі", Сезон 4, сер. 34, 15.11.17); Джентльмени, я запрошую Вас! (“Страсті за Ревізором", Сезон 5, вип. 11, 18.12.17).

1.3. Наступна ЛСП включає найменування закладів. Сюди входять уже досить звичні для носіїв української мови запозичення на зразок: супермаркет (англ. supermarket), напр.: Як я не люблю изі міські супермаркети - та ні поторгуватися, ні полаятися! (“Київ вдень та вночі”, Сезон 4, сер. 30, 08.11.17). Новим, однак уже широковживаним, $\epsilon$ запозичення барбершоп (англ. barbershop) — 'перукарня, що спеціалізується на чоловічих зачісках та голінні'3, напр.: Я під час того Свробачення, в його розпал, поӥхав в барбершоп підстригти бороду. Барбершоп, то таке саме як перукарня, тільки в перукарні двісті п'ятдесят гривень за стрижку бороди рука не піднімається заплатити, а в барбершопі - в самий раз (“Вар'яти”, Сезон 2, вип. 3, 15.11.17).

1.4. Найменування професій та видів діяльності. У дискурсі розважальних програм часто можна зустріти лексеми на позначення професій із суфіксом -мен та -ер: бізнесмен, бармен, стейджмен (англ. stageman - 'помічник на знімальній площадці фільму чи телешоу'4), блогер (англ. blogger — 'людина, яка $\epsilon$ автором блогу - мережевого журналу чи щоденника подій'5), напр.: Ксюша з Богданом вирішили позмагатись у тому, хто з них крутіший бізнесмен („Київ вдень та вночі”, Сезон 4, сер. 31, 09.11.17); Бармен! Бармен! Бочку! Та якого пива? Горілляки! (“Вар'яти”, Сезон 2, вип. 5, 29.11.17); Hi, я радий, що ти приєднався до нашого стейджмена $і$ допомагаєщ, в тебе изе вправніше виходить (“Страсті за Ревізором”, Сезон 5, вип. 5, 6.11.17); Народ, тому вам на замітку: побачите блогерів - або тікайте, або навіть не намагайтеся їм збрехати (“Київ вдень та вночі”, Сезон 4, сер. 25, 31.10.17). Трапляється також похідна лексема, утворена афіксальним способом від слова піap (англ. $\boldsymbol{P R}$ - public relations - 'Зв'язки з громадськістю') - niapниця, напр.: Cвimлано Олексї̈но, та не звертайте уваги, це наша піарниця територію мітить (“Київ вдень та вночі”, Сезон 4, сер. 45, 05.12.17).

1.5. До цієї ЛСП увійшли лексеми зі сфери інформаційних технологій: смартфон (англ. smartphone), айфон (англ. іPhone), імейл (англ. e-mail), селфi (англ. selfie), скрін (скорочено від скріншот ( англ. screenshot) — 'знімок екрану') і т. д. Напр.: Один дядя хотів купити одній тьоті смартфон на День народження. Про ие дізнався його син і тепер, щоб про ие не дізналася мама, тато купляє смартфон $і$ для тьоті і для сина (“Вар'яти”, Сезон 2, вип. 5, 29.11.17); Якщо Владзьо виграє - а хто виграв в кіниі батлу ви визначаєте свойми оплесками - то я, так $і$ бути, покажу йому, як розблокувати той айфон (“Вар'яти”, Сезон 2, вип. 4, 22.11.17); Tут приходить адміністратор з роздрукованим листом і каже: „Сергій, нам на імейл прийшов якийсь ось лист: чоловікові не сподобалося у нас на конщерті (“Вар'яти”, Сезон 2, вип. 3, 15.11.17); До нас приїхало десятки тисяч іноземців - вся Свропа, весь світ приїхали до Києва і всі ходили по столиці з фотоапаратами, і всі фоткали і робили селфі (“Вар'яти",

${ }^{3}$ Словотвір, [в:] Електронний ресурс: https://slovotvir.org.ua/words/barbershop (20.01.2018).

4 Merriam-Webster Dictionary, [in:] Electronic resource: https://www.merriam-webster.com/ dictionary/stageman (14.01.2018).

${ }^{5}$ Словотвір... 
Сезон 2, вип. 3, 15.11.17); Давайте пригадаємо, я попрошу скріни вивести на екран (“Страсті за Ревізором”, Сезон 5, вип. 11, 18.12.17).

1.6. Іншомовні лексеми зі сфери сценічного та телевізійного мистецтва: контемn (скорочено від англ. contemporary dance - 'сучасний танець'), xinxon (англ. hip-hop), шоy (англ. show) та похідні від нього складні іменники шоу-бізнес (англ. show business) і шоу-біз, сnешл гесm-cmap (англ. special guest star - 'відома особа, яка запрошена на концерт або на зйомки телевізійної програми'), селебрimi (англ. Celebrity - 'знаменитість'), універбат стриптизер$\kappa \boldsymbol{a}$ (англ. striptease, від strip - 'роздягатися', tease - 'дражнити') та його калькований розмовний варіант з російської мови стріптізьорша тощо, напр.: $B$ якому стилі працюєте? - В стилі концерт. - Можливо контемп? ("Вар'яти", Сезон 2, вип. 3, 15.11.17); Хочу на таниі, хочу xin-xоn (“Вар'яти”, Сезон 2, вип. 5, 29.11.17); Панове, в старі добрі часи подібне дійство називали “иирк на дроті" - ми з хлопиями називаємо иее Вар'яти-шоу (“Вар' яти”, Сезон 2, вип. 4, 22.11.17); Я вже давно помітив, щуо в Україні люди якось собі трошки хибно уявляють рівень статків людей, які працюють в украйнському шоу-бізнесі (“Вар'яти”, Сезон 2, вип. 1, 01.11.17); Краще б Пашок не на шоу-біз замахувався, а на прорив Каріниних почуттів і тоді слова пісні складуться самі собою (“Київ вдень та вночі”, Сезон 4, сер. 39, 23.11.17); На сиені з'явиться Володимир Жогло і спешл гест-стар Вар'яти-шоу - Надя Мейхер (“Вар'яти”, Сезон 2, вип. 4, 22.11.17); Сьогодні Наталя Кудряшова у нас на гостьовому диванчику, тому щзо вона сьогодні прийлла до нас не як "Ревізор. Магазини", а просто як гостя, як селебріті, яка поділиться власними враженнями ("Страсті за Ревізором", Сезон 5, вип. 11, 18.12.17); Стриптизерка зрозуміла, щзо їй пора на пенсію, коли вона зайшла в кабінку і ій сказали: "Слава Ісусу Христу!" (“Вар' яти”, Сезон 2, вип. 4, 22.11.17); А ти шоб понімала собі, стріптізьорш визивати в караоке-бар изе капєи як дорого! (“Ігри приколів”, вип. 1, 2017).

1.7. Лексеми іншомовного походження, що позначають родинні, дружні та інтимні стосунки: cicmep (англ. sister - сестра), френд (friend - друг, подруга) та жіночий рід цього іменника, утворений за допомогою додавання українського суфікса - $a$, френда, фрі-лав (англ. free love - вільне кохання) тощо, напр.: I добре, щуо на сполох почала бити Христя, яку чуйка абсолютно не підвела і вказала на те, щзо ї̈ люба сістер у небезпеці (“Київ вдень та вночі", Сезон 4, сер. 45, 05.12.17); Ксюша, зараз новоспечена френда тобі все пояснить, щзо $i$ де змінилось" (“Київ вдень та вночі", Сезон 4, сер. 31, 09.11.17); Інша річ Еп і Настя - у них фрі-лав, а значить ніяких тобі теш та свекрух, хоча проблем у них від того не менше (“Київ вдень та вночі", Сезон 4, сер. 27 , 02.11.17).

1.8. Різноманітні привітання та звертання до групи людей, які широко використовуються в розважальних телепередачах. Їх уживають у різних комбінаціях та з різними українськими суфіксами, що свідчить про їхню високу словотвірну активність. Найчастіше використовують такі запозичення, як: хей (англ. hey - 'привіт'), хелоу (англ. hello — 'привіт'), хелоу еврібаді (англ. hello everybody - 'привіт усім'), ninли (англ. people — 'люди'), хаюшки (англ. hi — 'привіт'), велкам my (англ. welcome to — 'ласкаво просимо до'), nic (англ. peace — 'мир'), френди (англ. friends — 'друзі'), етеншен (англ. attention — 'увага'), гайc (англ. guys - 'хлопці') тощо. Останне запозичення гайс на сьогодні демонструє найбільшу словотвірну активність 3-поміж інших неозапозичень у галузі розважальних телепрограм, адже від нього утворюють безліч форм 3 най- 
різноманітнішими закінченнями: гайзулі, гайзики, гайзи і т. д., напр.: Хей, гайс, усім привіт! (“Київ вдень та вночі”, Сезон 4, сер. 2, 20.09.17); Хелоу, еврібаді! (“Київ вдень та вночі”, Сезон 4, сер. 34, 15.11.17); Хелоу, піпли! (“Київ вдень та вночі", 21.11.17); Піпли, а знаєте, я за баланс у изьому житті, тому впевнений, щуо кожен отримає за свої вчинки те, щуо заслуговує (“Київ вдень та вночі", Сезон 4, сер. 39, 23.11.17); ,ННарод, усім хаюшки!” („Київ вдень та вночі”, Сезон 4, сер. 45, 5.12.17); „Добрий вечір, пані та панове, велкам ту Вар'яти-шоу!' („Вар' яти”, Сезон 2, вип. 3, 15.11.17); ,НАарод, усім nic!” („Київ вдень та вночі”, Сезон 4, сер. 29, 07.11.17); Мої френди, а ось якраз нам і випала можливість трохи познайомитись з новим побутом Паші (“Київ вдень та вночі”, Сезон 4, сер. 2, 20.09.17); A тепер етеншен! Інтрига ("Київ вдень та вночі", Сезон 4, сер. 46, 07.12.17); Гайс, ну хіба не прекрасна новина! (“Київ вдень та вночі”, Сезон 4, сер. 46, 07.12.17); Гайзулі, давайте не будемо вишукувати підтекстів, а з '̈мо все буквально, так як $і$ було сказано Епом (“Київ вдень та вночі", Сезон 4, сер. 41, 28.11.17); Гайзики, і такі ситуачї трапляються, коли починає грати та ставка, на яку ми найменше очікуємо в цей момент ("Київ вдень та вночі", Сезон 4, сер. 25, 31.10.17); Просто, гайзи, бережіть своїх мам і їхі нерви (“Київ вдень та вночі”, Сезон 4, сер. 30, 08.11.17).

1.9. Іншомовні лексеми, що слугують для опису різних життєвих ситуацій. Особливістю цієї ЛСП є те, що сюди входять не лише іменники, а й прикметники англомовного походження: бед дей (англ. bad day - 'поганий день'), кульний (англ. утворений афіксальним способом від англ. cool - 'класний, прохолодний'), трабли (англ. trouble - 'неприємність, турбота') - в українській мові це неозапозичення вживається, як правило, у множині та демонструє високу словотвірну активність і набуває категорії відмінка іменника української мови - траблів, траблами тощо.), хепі енд (англ. happy end - 'щасливий кінець'), хепі момент (англ. happy moment - 'щасливий момент') тощо, напр.: I з думкою, щзо ніхто ні в чому не винен, нарешті відпустимо иеей бед дей ("Київ вдень та вночі", Сезон 4, сер. 41, 28.11.17); Тільки варто було потішитись, який сьогодні видався кульний деньок - одразу ж все розвернулося навпаки ("Київ вдень та вночі", Сезон 4, сер. 27, 02.11.17); А тим часом Біня і Володькович, аби вирішити свої трабли, вирішили розіграти перед мамами цілу виставу ("Київ вдень та вночі", Сезон 4, сер. 31, 09.11.17); А до Епа ввечері нагрянув незваний гість зі своїми траблами (“Київ вдень та вночі", Сезон 4, сер. 30, 08.11.17); Яна і Борисович, після всіх траблів з викраденнями, нарешті остаточно знайшли спільну мову зі своїми дочями (“Київ вдень та вночі”, Сезон 4, сер. 47, 07.12.17); Та якщзо раптом хтось Вам скаже, щзо всі ияі історії безглузді - не вірте, бо хепі енд можливий $і$ ми щуойно стали цььому свідками ("Київ вдень та вночі", Сезон 4, сер. 48, 08.12.17); Тому давайте вже дивитися, щоб не профукати хепі момент у цій вері (very - дуже, прим. автора) заплутаній історії ("Київ вдень та вночі", Сезон 4, сер. 37, 21.11.17).

До другої групи запозичень у дискурсі розважальних жанрів українського телебачення входять лексеми, що звузили своє значення. На сьогодні виокремлено дві ЛСП запозичень зі звуженою семантикою:

2.1. Запозичення, пов'язані зі сферою фінансів та комерційною діяльністю. Сюди ввійшли такі широковживані лексеми, як: бізнес, спонсор, прайс, бакс та ін. Запозичення бізнес (англ. business) є звичним для українців і давно зафіксоване в тлумачних словниках та спеціальній літературі. В українській мові і в розважальних жанрах зокрема — бізнес позначає 'торговельну, підприєм- 
ницьку, біржову діяльність, спрямовану на одержання прибутків'․ Ця лексема освоєна на всіх рівнях української мови й набула категорії відмінка: бізнес - бізнеса - бізнесу - бізнесом - бізнесі. Напр.: Чоловік нібито займається бізнесом (“Страсті за Ревізором", Сезон 5, вип. 11, 18.12.17). Утім, значення цієї лексеми в мові-джерелі значно ширше: '1) комерційна діяльність як спосіб заробити кошти на проживання; комерційне або інколи індустріальне підприємство; угода; транзакція; 2) роль, функція; термінове завдання; окрема галузь виробництва; 3) справа (в загальному значенні); 4) особиста справа; право; 5) серйозна справа, що вимагає концентрації та зусиль; 6) процес створення; 7) дія або рух (напр., запалювання сигарети), що виконані актором на сцені з метою створення особливої атмосфери, розкриття персонажу та ситуації - називається також stage business"

Іншою лексемою зі звуженою семантикою $є$ запозичення спонсор (англ. sponsor). В українських розважальних програмах його вживають у значенні 'особа чи організація, що матеріально підтримують будь-яку діяльність без одержання від неї прибутку з метою популяризації винятково свого імені (назви), торгової марки", напр.: Комфі - наш інноваційний спонсор (“Вар'яти”, Сезон 2, вип. 4, 22.11.17). Англомовний прототип цієї лексеми має дещо ширшу семантику: '1) особа, яка представляє кандидата на хрещення чи посвячення і бере на себе відповідальність за релігійне виховання особи чи іiі духовне благополуччя; 2) особа, яка бере на себе відповідальність за іншу людину чи річ; 3) особа чи організація, яка платить чи планує та реалізує проект чи діяльність; особа, яка оплачує вартість радіо- чи телепрограми, зазвичай в обмін на рекламу'

Зі сфери фінансів також походить запозичення прайс. Ця лексема є скороченим варіантом запозичення прайс-лисm (англ. price list, де price - 'ціна', list - 'список') — 'нормативно-виробниче і (або) довідкове видання, що містить систематизований перелік матеріалів, виробів, обладнання, виробничих операцій, послуг із зазначенням цін, а іноді коротких характеристик' ${ }^{10}$, напр.: Що у тебе беруть овер (over - понад, прим. автора) того прайсу, що сплачується за номер? (“Страсті за Ревізором”, Сезон 5, вип. 6, 13.11.17). Проте, скорочений варіант прайс, який можна почути в українських розважальних телепрограмах, має ширше значення в мові-джерелі: '1) цінність; 2) вартість одного предмета, який обмінюється чи проситься в обмін на інший або ж продається; кількість грошей, яка дається або встановлюється за певний предмет; 3) кількість грошей чи цінностей, за яку можна когось підкупити; нагорода за захоплення чи смерть розшукуваного злочинця; 4) вартість чогось абстрактного як иүіна свободи — the price of freedom'll.

У мові розважальних телешоу також активно використовують лексему бакс (у множині бакси). Це запозичення прийшло до української мови 3 англоамериканського сленгу. У США bucks (і також у всьому світі) 一 це розмовна назва доларів (dollars) — національної валюти Сполучених Штатів Америки. В українській мові засвоїлося саме сленгове значення цього слова, але в ан-

\footnotetext{
${ }^{6}$ Тлумачний словник украӥнської мови, авт.-уклад. А. Івченко, Харків 2006, с. 30.

${ }^{7}$ Merriam-Webster Dictionary...

8 Тлумачний словник украӥнської мови, [в:] Електронний ресурс: http://eslovnyk.com

${ }^{9}$ Merriam-Webster Dictionary...

${ }^{10}$ Вікіпедія. Прайс-лист, [в:] Електронний ресурс: https://uk.wikipedia.org (10.01.2018).

${ }^{11}$ Merriam-Webster Dictionary...
} (05.02.2018). 
глійській мові воно має ширше значення: '1) самець тварини, найчастіше самець оленя чи антилопи; 2) особа чоловічої статі; спритний та енергійний чоловік; 3) долар; 4) сума зароблених грошей; гроші' ${ }^{12}$. Долари почали називати баксами саме через оленячу шкіру, адже ще в 1748 році, за 44 роки перед тим як з'явився долар, було зафіксовано продаж корінним американцям бочки віскі за 5 баксів, тобто 5 оленячих шкір, що свідчить про те, що в той період бак$\boldsymbol{c u}$ були своєрідною валютою ${ }^{13}$. В українській мові ця лексема зазнала звуження семантики, тому й уживають ії лише для позначення американської валюти i, як і в мові-джерелі, іï зазвичай використовують у розмовному та розважальних жанрах публіцистичного стилю, напр.: По машині все ясно. До завтра все зробим, ну, плюс-мінус, сто баксів це буде коштувати (“Вар'яти”, Сезон 2, вип. 5, 29.11.17); Це бокали Сваровські, я для нас замовила... Сто n'ятдесят баксів (“Ігри приколів”, вип. 1, 2017).

2.2. Другу підгрупу запозичених лексем зі звуженою семантикою складають англіцизми, пов'язані із галузями естради, кіномистецтва та телебачення. До цієї групи увійшли такі англіцизми, як рейтинг (англ. rating), кастинг (англ. casting), бенд (англ. band), продюсер (англ. producer), флешбек (англ. flashback) та ін. Ці лексеми демонструють глибокий ступінь освоєння та набувають категорії відмінка української мови. Запозичення рейтинг в англійській мові має декілька значень: '1) класифікація за ступенем; зокрема військова чи воєнно-морська спеціалізація; 2) брит. особа, яка служить на флоті; 3) відносна оцінка; оцінка відповідальності окремої особи, чи підприємства, чи організації; оцінка відсотка загального прослуховування чи перегляду конкретної теле- чи радіопередачі; 4) заявлена робоча межа механізму, яка виражається в кіловатах чи інших характеристиках ${ }^{\prime 14}$. В українській мові це слово засвоїлося в значеннях показника оцінки діяльності якоїсь особи, групи чи організації та позначення частини цільової аудиторії, що контактує 3 конкретним медіаносієм й вимірюється або кількістю людей, або у відсотках до загальної чисельності населення ${ }^{15}$. У розважальних жанрах лексему рейтинг використовують для позначення якості успішності телепрограми, напр.: На телебаченні головне щзо? Рейтинги! Ну, грубо кажучи, мій кум садить рейтинг Нового каналу ("Вар'яти", Сезон 2, вип. 4, 22.11.17).

Лексема кастинг також має більше значень у мові-джерелі: '1) процес перенесення розплавленої сталі на форму; 2) відбір акторів для зйомок фільму чи вистави; 3) направлення зграї гончих псів на територію, де могла ходити їхня здобич, для того, щоб вони могли відчути ії запах'16. У розважальних телепрограмах та українській мові слово кастинг уживають для найменування процесу відбору 3-поміж інших претендентів людини, яка найбільшою мірою підходить для ролі в певному фільмі, виставі, шоу тощо, напр.: А ось поки Apmyp успішно провалював свій кастинг, до Діани вдома навідалися дуже несподівані гості (“Київ вдень та вночі”, Сезон 4, сер. 44, 01.12.17).

Запозичення бенд також суттєво звузило свою семантичну структуру. В англійській мові це слово позначає: '1) групу молодих чоловіків чи жінок, які

${ }^{12}$ Там само.

13 Today I found out, [в:] Електронний pecypc: http://www.todayifoundout.com/index. php/2014/03/dollar-called-buck_ (05.01.2018).

${ }^{14}$ Merriam-Webster Dictionary...

${ }^{15}$ Вікіпедія...

${ }^{16}$ Collins Dictionary, [в:] Електронний pecypc: https://www.collinsdictionary.com/dictionary/ english/casting (04.01.2018). 
виконують популярні пісні разом чи танцюють як група; 2) тонкий плоский шматок тканини, еластичного матеріалу, металу тощо, який щось обгортає; 3) певний діапазон значень, чисел' ${ }^{17}$. У галузі розважальних жанрів запозичення бенд уживають як найменування групи музикантів й танцюристів, напр.: Я за той квиток відвалив скільки бабла, щзо я думав, щзо хореографію дітям ставив Влад Яма, а виступ буде йти під супровід Тіни Кароль. Наживо. 3 бендом (“Вар'яти”, Сезон 2, вип. 5, 29.11.17).

Англомовна лексема продюсер у мові українського телебачення означає: 'довірена особа кінокомпанії, яка здійснює ідейно-художній та організаційнофінансовий контроль над постановкою фільму, вистави, телепрограм, концертів тощо' ${ }^{\prime 18}$, напр.: Та все ж погоджуюсь, що простіше буде переконати продюсера все переробити, ніж зуміти пояснити Діані, щзо тепер у Артура така робота (“Київ вдень та вночі", Сезон 4, сер. 46, 06.12.17). Проте в англійській мові ця лексема має дещо ширшу семантику: '1) особа, яка відповідає за організацію та фінансування фільму, вистави, теле- чи радіопрограми, запису музичного альбому тощо; 2) компанія, країна або особа, яка надає товари, особливо ті, які виробляються в промисловому процесі або вирощуються чи отримуються за рахунок сільського господарства, як правило, у великій кількості' ${ }^{19}$.

Доволі новим запозиченням, що функціонує в розважальних телепрограмах українського телебачення, є лексема флешбек. Це слово вживають для позначення 'зворотного кадру, ретроспективи, сцени з минулого, оформленої як спогад та вмонтованої у потік поточної розповіді чи зображення'20, напр.: $\mathrm{Ha}$ род, якщзо ви забули - флешбек з минулого про ту урочисту мить, про яку зараз говорить Артур (“Київ вдень та вночі", Сезон 4, сер. 41, 28.11.17). Однак прототип цього запозичення в англійській мові, окрім наведеного вище значення, має ще одне: 'раптовий, дуже чіткий спогад про минулу подію чи період, зазвичай неприємний чи болісний ${ }^{21}$.

Третю групу запозичень, що зазнали змін своєї семантичної структури, складають іншомовні лексеми, які розширили значення. На сьогодні зафіксовано такі англіцизми з розширеною семантикою в дискурсі українських розважальних телепрограм: opic (англ. office), xобi (англ. hobby), кеш (англ. cash).

Лексема офіс давно освоєна усіма рівнями української мови і є звичною майже для кожного українськомовного громадянина. Значення цього запозичення збігається із семантикою його прототипу в мові-джерелі: 'нежитлове приміщення, що належить суб'єкту господарювання, де міститься його виконавчий орган і яке має певну адресу, через яку можна здійснювати поштовий 3в'язок' ${ }^{\prime 2,23}$. Проте в розважальних програмах запозичення офic може набувати нового значення, напр.: Ну, я вийшов, обійшов, захожу з боку в ті двері, відкриваю - а там сидять священики, якісь монашки... Ну, короче, я так поняв, офіс mам в них (“Вар'яти”, Сезон 2, вип. 5, 29.11.17). Отже, тепер ця лексема може вживатися не лише для найменування ділових контор зі спеціальним технічним обладнанням, а й для позначення робочого приміщення.

${ }^{17}$ Cambridge Dictionary, [в:] Електронний pecypc: https://dictionary.cambridge.org/dictionary/ english/band (04.01.2018).

${ }^{18}$ Тлумачний словник украӥнської мови...

${ }^{19}$ Cambridge dictionary...

${ }^{20}$ Словотвір...

${ }^{21}$ Cambridge dictionary...

${ }^{22}$ Великий тлумачний словник сучасної української мови, [в:] Електронний ресурс: http:// www.wikiwand.com. (28.12.2017).

${ }^{23}$ Merriam-Webster Dictionary... 
Запозичення хобі також дещо розширило семантику. В англійській мові $\boldsymbol{x}$ юбi означає 'заняття, що не є робочою спеціальністю і до якого людина вдається в неробочий час для отримання задоволення' ${ }^{24}$. Проте в наведеному далі прикладі проілюстровано, як це слово розширює семантику й отримує жартівливий підтекст, порівн.: Ви знаєте, я дуже люблю помитися... - Яке иікаве хобі! (“Страсті за Ревізором”, Сезон 5, вип. 11, 18.12.17).

Лексема кеш теж розширила семантичну структуру порівняно зі своїм англомовним прототипом. В англійській мові кеш (cash) — це 'гроші у формі монет та готівки'25. У розмовній українській мові це слово використовують не тільки для позначення готівки, а й для найменування фінансів у загальному значенні, напр.: Розумієш, тут треба фінансові вливання... - Так, може я твої борги вичеркну... - Hi, mут треба кеш (“Одного разу під Полтавою”, 2017).

Четверту групу запозичень у розважальних жанрах українського телебачення репрезентують слова іншомовного походження, що набули іншого значення порівняно зі своїми прототипами в мові-джерелі. На сьогодні в українському мовознавстві існує думка, що запозичені лексеми, які змінили значення за період функціонування в українській мові, трапляються зрідка ${ }^{26}$. Проте аналіз іншомовних лексем у дискурсі розважальних телепрограм засвідчив, що у зв'язку 3 надзвичайно інтенсивним процесом проникнення нових запозичень до української мови зміна їхньої семантики відбувається все частіше. Автори телевізійних програм уживають запозичення не просто як іншомовні вкраплення, вони творчо обробляють їх та використовують у найрізноманітніших контекстах для підсилення експресивності та образності мовлення.

Зміни семантики зазнали такі англіцизми: перформанс (англ. performance), mpeш (англ. trash), фоллауm (англ. fallout). Слово перформанс зазвичай уживають у значенні 'одна із форм мистецтва, де твором вважають дії автора, за якими глядачі спостерігають у режимі реального часу'27. Однак все частіше це запозичення вживається в тому контексті, де йдеться про занадто емоційну (часто неадекватну) поведінку особи чи надмірну екзальтованість. Фраза влаштовувати перформанс стала синонімом фрази влаштовувати скандал, сцену чи істерику, напр.: Пташко, Настю тільки везуть до палати, а не на той світ, нащо ти влаштовуєш иеей перформанс? ("Київ вдень та вночі", Сезон 4, cep. 37, 21.11.17).

Лексема треш також набула в українській мові значення, відмінного від англомовного прототипу. Англомовний словник дає таке визначення слова trash: '1) розм. низькоякісна річ; 2) сміття або речі, які більше не потрібні; 5) розм. пейоративне слово, яке вживають відносно особи або людей, яких зневажають' ${ }^{28}$. У дискурсі розважальних програм цю лексему вживають у значенні 'неприємна і (або) шокуюча, стресова ситуація', напр.: Щось я трохи не зовсім зрозумів... То Біня не жартувала? Вони дійсно вбили Артура? Ох і треш ("Київ вдень та вночі", Сезон 4, сер. 40, 24.11.17); Взагалі повний треш несеться у Біні з Володьковичом, а все через весільні клопоти, які не можуть вирішити їхні мами (“Київ вдень та вночі”, Сезон 4, сер. 30, 08.11.17).

${ }^{24}$ OxfordLearner's Dictionaries, [в:] Електроннийресурс: https://www.oxfordlearnersdictionaries. com/definition/english/hobby?q=hobby (20.12.2017).

25 Там само.

${ }^{26}$ I. О. Коробов а, Семантичне та словотвірне освоєння ..., с. 11.

${ }^{27}$ Словотвір...

${ }^{28}$ Cambridge Dictionary.... 
Іншим запозиченням, що набуло цілком нової семантики, є лексема фоллауm. В англійській мові fallout означає: '1) радіоактивні частки, що переміщуються або виникають у результаті ядерного вибуху та випадають радіоактивними опадами; 2) ефект, результат, наслідки'29. У молодіжному жаргоні та популярних молодіжних телепередачах це запозичення набуло значення 'шок, відчай', напр.: Ну, наприклад, у Біні стався повний фоллаут через сукню, яку обрав для неї коханий Володимирович (“Київ вдень та вночі", Сезон 4, сер. 25, 31.10.17).

Суттєво змінило значення порівняно зі своїм оригіналом запозичення лакuepi. Luxury перекладають 3 англійської як 'розкіш'. На початку свого функціонування в українській мові семантика цього запозичення збігалася із семантикою його англійського прототипу й уживалася в значенні 'сегмент ринку товарів і послуг люкс-класів' ${ }^{30}$, напр.: Лакшері - це дорого, якісно і часто, яскраво, лакшері - це престижно, солідно і майже завжди непомітно: саме ці характеристики традиційно називають маркетологи, визначаючи лекшерісегмент $^{30}$. Проте із часом воно набуло сатиричного й глузливого значення. Лак-

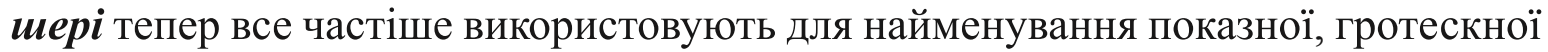
розкоші, а також прагнення людей із середнім достатком приєднатися до світу еліти, напр.: Ти щз, я не ходжу в такі заклади! - Чому? - Це ж не лакшеpi (“Страсті за Ревізором”, Сезон 5, вип. 9, 05.12.17). Подібних змін семантики зазнали також інші англіцизми, пов’ язані зі світом розкоші та багатства: ві ай ni (VIP — very important person - 'дуже важлива персона'), делюкс (deluxe - 'розкішний'), роял (royal - 'королівський'). Напр.: Чогось всі думають, щуо якщо тебе часто показують по тєліку, чи ти соліст якоїсь групи, чи ти телеведучий, то ти живеш в якомусь такому ефемерному світі ві ай пі, лакшеpi, делюкс, роял... I я відверто Вам скажу, щуо теж довгий час думав про себе, щзо я ві ай ni, лакшері, делюкс (“Вар'яти”, Сезон 2, вип. 1, 01.11.17). Часте вживання цієї лексеми саме в сатиричному значенні призвело до появи ії калькованого варіанту - лухарі. Лухарі стало визначенням поганого смаку та вульгарності. Иого використовують як антонім до слова розкіш. Лухарі може вживатися не тільки як окрема лексична одиниця, а й утворювати складні іменники з українською або іншомовною частиною, напр.: Тому, давайте не будемо діставати Насіка, а метнемся в лухарі-апартмент (apartment - квартира, прим. автора) до Діани та Арчі (“Київ вдень та вночі", Сезон 4, сер. 48, 08.12.17). У наведеному прикладі йдеться зовсім не про розкішні апартаменти, а про комунальну квартиру із жахливими умовами проживання. Усі ілюстрації, вибрані 3 розважальних телепрограм, свідчать про кардинальну зміну семантики слова luxury в просторі сучасної української мови.

Іншомовні слова не лише зазнають змін семантичної структури, вони також набувають різного стилістичного забарвлення. У мовленні розважальних жанрів українського телебачення було зафіксовано низку образних індивідуальноавторських метафор з використанням різноманітних англіцизмів:

- GPS-навizamop (англ. Global Positioning System - 'глобальна система позиціонування') — 'пристрій, що отримує сигнали глобальної системи позиціонування з метою визначення поточного місця розміщення пристрою на Землі' ${ }^{31}:$ То, певне, добре Львів знаєте? — Я-то знаю. Він каже: „,Ну, то пока-

\footnotetext{
${ }^{29}$ Merriam-Webster Dictionary...

${ }^{30}$ Словотвір...

${ }^{31}$ Вікіпедія, [в:] Електронний ресурс: https://uk.wikipedia.org (10.01.2018).
} 
жете як їхати”. Друзі, я працював найдорожчим в Украӥні GPS-навігатором (“Вар'яти”, Сезон 2, вип. 5, 29.11.17);

- zaджет (англ. gadget - 'річ, зазвичай електронна або яка має стосунок до електроніки, рахівника або Інтернету' ${ }^{32}$ ) та павербенк (роwer bank — 'портативний зарядний пристрій'): Мужики, скажіть, будь ласка, хто був присутній на пологах? Підніміть руку, хто від'єднував той гаджет від павербенка - хто відрізав пуповину? (“Вар'яти”, Сезон 2, вип. 4, 02.11.17);

- mecm-драйв (англ. test drive — 'пробна поїздка') — 'поїздка на автомобілі для оцінки його ходових, маневрених та візуальних характеристик'33: Aле чітко зрозуміти, хто така рідна людина, ми можемо лише з часом, коли пройдемо всі тест-драйви, які нам підготувала столиия (“Київ вдень та вночі, Сезон 4, сер. 30, 08.11.17);

- хендмейд (англ. handmade — 'ручна робота') — 'оригінальні речі ручної роботи без використання механізованих чи автоматизованих технологій' 34 та Юкрейніан роудс (Ukrainian roads - 'українські дороги'): А щзо ж ти хочеш? Юкрейніан роудс, хендмейд - ручна робота! (“Вар' яти”, Сезон 2, вип. 3, 15.11.17);

- aфmenami (англ. after party — 'після вечірки') продовження розважальної вечірки після основної частини, що може тривати до відходу останнього клієнта $^{35}:$ А поки всі так чекають, пропоную махнути на афтепаті у відділок - послухаємо, шзо чекає на Алю за ї̈ вбивче кохання („Київ вдень та вночі”, Сезон 4, cep. 45, 05.12.17).

Отже, уживання іншомовних лексем у мовленні розважальних телепрограм є динамічним й інтенсивним процесом. Більшу частину запозичених лексем становлять англіцизми. Причиною наявності такої великої кількості англіцизмів є поширеність і престиж англійської мови у світі й Україні зокрема.

Свідченням освоєння запозичень у системі мові-реципієнта є його семантична адаптація. 3 урахуванням типів змін семантичної структури запозичень було виділено чотири групи іншомовних лексем у мовленні розважальних телепрограм: лексеми, що не змінили свого семантичного обсягу, слова зі звуженням семантики й ті, що іiі розширили, а також запозичення, що набули нового, відмінного від прототипу значення на грунті української мови.

Серед лексем, що не зазнали семантичних змін, було виділено дев'ять лексико-семантичних підгруп, серед слів зі звуженою семантикою - дві. Запозичення $з$ розширеною семантикою поки що не так часто вживаються в мові розважальних шоу, проте спостерігаємо тенденцію до набуття іншомовними словами нових значень та стилістичних забарвлень. Інтенсивність і безперервність процесу запозичення чужомовних слів в українську мову та їхнє використання в різних жанрах телебачення зумовлює необхідність подальших наукових розвідок у цьому аспекті.

\section{Список використаної літератури}

Великий тлумачний словник сучасної української мови, [в:] Електронний ресурс: http:// www.wikiwand.com (28.12.2017).

Вікіпедія, Прайс-лист, [в:] Електронний ресурс: https://uk.wikipedia.org (10.01.2018).

\footnotetext{
${ }^{32}$ Словотвір...

${ }^{33}$ Там само.

34 Там само.

35 Там само.
} 
Коробова I. О., Семантичне та словотвірне освоєння новітніх запозичень в украйнській мові, автореф. дис. ... канд. філол. наук, Запоріжжя 2018.

Навальна М. І., Динаміка лексикону української періодики початку XXI cm., Київ 2011.

Словотвір, [в:] Електронний ресурс: https://slovotvir.org.ua (20.01.2018)

Тлумачний словник украӥнської мови, [в:] Електронний ресурс: http://eslovnyk.com (05.02.2018).

Тлумачний словник украӥнської мови, авт.-уклад. А. Івченко, Харків 2006.

Cambridge Dictionary, [in:] Electronic resource: https:/dictionary.cambridge.org/dictionary/ english/band (04.01.2018).

Collins Dictionary, [in:] Electronic resource: https://www.collinsdictionary.com/dictionary/ english/casting (04.01.2018).

Merriam-Webster Dictionary, [in:] Electronic resource: https://www.merriam-webster.com/ dictionary (14.01.2018).

Oxford Learner's Dictionaries, [in:] Electronic resource: https://www.oxfordlearnersdictionaries.com/definition/english/hobby?q=hobby (20.12.2017).

Today I found out, [in:] Electronic resource: http://www.todayifoundout.com/index. php/2014/03/dollar-called-buck (05.01.2018).

\section{Spysok vykorystanoi literatury \\ [References]}

Velykyi tlumachnyi slovnyk suchasnoi ukrainskoi movy [Big Explanatory Dictionary of Modern Ukrainian], [v:] Elektronnyi resurs: http://www.wikiwand.com (28.12.2017).

Vikipediia, Prais-lyst [v:] Elektronnyi resurs: https://uk.wikipedia.org (10.01.2018).

Korobova I. O., Semantychne ta slovotvirne osvoiennia novitnikh zapozychen v ukrainskii movi [Semantic and Word-Formation Functioning of New Borrowings in the Ukrainian Language], avtoref. dys. ... kand. filol. nauk, Zaporizhzhia 2018.

Navalna M. I., Dynamika leksykonu ukrainskoi periodyky pochatku XXI st. [Dynamics of Ukrainian Periodicals Lexicon of the Beggining of the XXIst century], Kyiv 2011.

Slovotvir [Word-Formation], [v:] Elektronnyi resurs: https://slovotvir.org.ua (20.01.2018)

Tlumachnyi slovnyk ukrainskoi movy [Explanatory Dictionary of the Ukrainian Language], [v:] Elektronnyi resurs: http://eslovnyk.com (05.02.2018).

Tlumachnyi slovnyk ukrainskoi movy [Explanatory Dictionary of the Ukrainian Language], avt.-uklad. A. Ivchenko, Kharkiv 2006.

Cambridge Dictionary, [in:] Electronic resource: https://dictionary.cambridge.org/dictionary/ english/band (04.01.2018).

Collins Dictionary, [in:] Electronic resource: https://www.collinsdictionary.com/dictionary/ english/casting (04.01.2018).

Merriam-Webster Dictionary, [in:] Electronic resource: https://www.merriam-webster.com/ dictionary (20.12.2017).

Oxford Learner's Dictionaries, [in:] Electronic resource: https://www.oxfordlearnersdictionaries.com/definition/english/hobby?q=hobby (20.02.2018).

Today I found out, [in:] Electronic resource: http://www.todayifoundout.com/index. php/2014/03/dollar-called-buck (05.01.2018). 